\title{
Prevalence of Scabies in Duhok Province and Duhok Refugees' Camps- Kurdistan Region of Iraq
}

\author{
Arshad Mohammad Abdullah (Corresponding author) \\ College of Pharmacy, University of Duhok, Iraq \\ E-mail: arshadzanko@gmail.com \\ Mehvan J. Muhammad \\ College of Pharmacy, University of Duhok, Iraq \\ Darya S. Hussein \\ College of Pharmacy, University of Duhok, Iraq \\ Ruwiada M. Abdullah \\ College of Pharmacy, University of Duhok, Iraq \\ Salar M. Hassan \\ College of Pharmacy, University of Duhok, Iraq
}

\begin{abstract}
Scabies is one of the important dermatologic problems with worldwide distribution everywhere, especially in developing countries and Iraq. The aim of current study is to determine the exact status of scabies infestation in Duhok province and some Duhok refugees' camps in order to get better management and control of scabies disease. The prevalence of Scabies was $5.52 \%$ and $5.45 \%$ in both Duhok province and Duhok refugees' camps respectively, the incidence was higher in female in both Duhok province (52.41\%) and Duhok refugees' camps (57.89\%). The highest scabies incidence was shown in 31-40 years age group, and the lowest incidence in 50 years and over age group. The highest infestation percentage was recorded in January $(19.90 \%)$ and February $(16.10 \%)$ and the lowest infestation percentage in April (9.80\%) and July (6.70\%). According to education status of infested patients, in Duhok province and Duhok refugees' camps the infestation rate of illiterate patients recorded in $85 \%$ and $95 \%$ respectively.
\end{abstract}

Keywords: Sarcoptes scabiei, Scabies infestation, Skin infection, Duhok province, health centres.

DOI: $10.7176 / \mathrm{JSTR} / 6-11-03$

\section{Introduction}

Scabies is an epidermal parasitic disease which is caused by Sarcoptes scabiei, it is an obligatory ectoparasite which infests human skin (Hay et al., 2012). Scabies is one of worldwide distribution disease which is reported 300 million cases approximately per year (Hengge et al., 2006). However, it is very difficult to assess global problem scale, because there is no uniform reporting system. Epidemiological reports are based on different information sources, which include case reports of military organs and national system or other centres such as care facilities centres, hospitals and schools (Mounsey et al., 2013). World Health Organization (WHO) listed scabies in Neglected Tropical Diseases and every year many researchers and professionals are meeting together and reports their findings (Thomas et al., 2015; Engelman et al., 2013). Scabies disease reported in all social classes, all age groups, immunocompromised patients, care facilities residents or overpopulated places with low socioeconomic level (Engelman et al., 2013). Scabies parasites infest many parts of human body and symptoms include cutaneous lesions, rashes in skin, subcutaneous tunnels, nocturnal skin pruritus and itching, allergic reaction, secondary bacterial infections (Golchai et al., 2003; Daliri\&Shafiei, 1994), also antigenic and toxic secretions by male mite which caused to scabies lesions (Jarmuda et al., 2012;

24 | P a g e

www.iiste.org 
Elder et al., 2006). Female mite by formation of small irregular skin tunnel can produce cutaneous lesions (Walton and Currie, 2007; Chosidow, 2006). Transmission routes of Scabies disease most often occur by direct contact with infested person also through fomites and sexual intercourse with infested person (Otero et al., 2004). Because of high infestation rate of scabies disease, it is necessary that all members of family undergo treatment as other person who has direct contact with infested individual (Walton, 2010). Many reports shown that there is strong correlation between seasons, low temperature and high humidity with longer scabies survival time (Arlian et al., 1984). Many studies about scabies prevalence have been reported by various researchers, and due to the high infestation of this parasite and importance of health system, treatment, good preventive measures and therapeutic techniques, it is too important to prepare special programs for dissolving of this disease. The aim of this study is to find out the prevalence and epidemiology of scabies and its correlation with age groups, sex and socioeconomic level of patients in Duhok province and refugees' camps.

\section{Material and Methods}

\section{Study area}

This study was done in Duhok Province and several refugees' camps, of Kurdistan region of Iraq. All data were collected during the period of January to August of 2019. In current study, 4 health centers of Duhok province (Azadi teaching hospital, Zakho's general hospital, Semel and Bardarash health sections) and 4 refugees' camps were considered for assessment (Darkar Camp, Bersive Camp 1 and Bersive Camp 2, and Chamishku Camp).

\section{Study design}

During this period, a total of (35447) patients with skin infections were attended hospitals and camps health centers and all attendance patients were recorded according to residency, gender, age groups, educational level, season or date of hospital attendance. In this study all patients were diagnosed and examined by dermatologists, and the diagnosis most commonly based on the clinical features of the patients and sometimes microscopically identification or by using dermatoscope in unclear cases to ensure the presence of scabies. The approval of ethics committee was taken from directorate general of health in Duhok province. The difference in the prevalence of scabies between male and female subjects was examined in Pearson Chi-squared test. The significant level of difference was determined in a P-value of less than 0.05 .

\section{Results}

Recent study was based on studding of 35447 skin patients in Duhok province and Duhok refugees'camps, the total of 29183 skin patient in Duhok province and 6264 skin patients in Duhok refugees' camps were studied in both gender with different age ranges from one to over 50 years, which are shown in table No. (1) and (2). The total infested patients with scabies in Duhok province was $5.52 \%$, with $47.58 \%$ male and $52.41 \%$ female infestation and according to the age groups the highest prevalence of scabies was $27.29 \%$ in age group (31-40Years) and the lowest prevalence was $7.07 \%$ in age group ( $\geq 50$ Years), as shown in table No. (1).

Table (1): Prevalence of scabies infestation in Duhok province

\begin{tabular}{|c|c|c|c|c|c|}
\hline $\mathrm{N}=\mathbf{2 9 1 8 3}$ & \multirow{2}{*}{$\begin{array}{l}\text { Infested with } \\
\text { scabies }\end{array}$} & \multirow[t]{2}{*}{ Male } & \multirow[t]{2}{*}{ Female } & \multirow{2}{*}{$\begin{array}{c}\text { Education } \\
\text { status }\end{array}$} & \multirow[t]{2}{*}{ P-Value } \\
\hline Age Group & & & & & \\
\hline 0-10 & $154(9.55 \%)$ & $75(48.7 \%)$ & $79(51.29 \%)$ & $85 \% /$ & 0.761 \\
\hline $11-20$ & $244(15.13 \%)$ & $120(49.18 \%)$ & $124(50.81 \%)$ & (Illiterate) & \\
\hline 21-30 & $309(19.16 \%)$ & $148(47.89 \%)$ & $161(52.1 \%)$ & & \\
\hline $31-40$ & $440(27.29 \%)$ & $209(47.5 \%)$ & $231(52.5 \%)$ & & \\
\hline $41-50$ & $351(21.77 \%)$ & $153(43.58 \%)$ & $198(56.41 \%)$ & & \\
\hline$>\mathbf{5 0}$ & $114(7.07 \%)$ & $56(49.12 \%)$ & $58(50.87 \%)$ & & \\
\hline Total & $1612(5.52 \%)$ & $767(47.58 \%)$ & $845(52.41 \%)$ & & \\
\hline
\end{tabular}

25 | P a g e 
In Duhok refugees' camps the infested rate was $5.45 \%$, with $42.10 \%$ of male and $57.89 \%$ of female and the highest infested rate was $22.8 \%$ in age group (31-40 Years) and lowest infested rate in age group ( $\geq$ 50 Years) with $11.11 \%$. (Tab. No. 2).

Table (2): Prevalence of scabies infestation in Duhok refugee's camps.

\begin{tabular}{|c|c|c|c|c|c|}
\hline $\begin{array}{c}\mathrm{N}=6264 \\
\text { Age Group }\end{array}$ & $\begin{array}{l}\text { Infested with } \\
\text { scabies }\end{array}$ & Male & Female & $\begin{array}{c}\text { Education } \\
\text { status }\end{array}$ & P-Value \\
\hline $0-10$ & $42(12.28 \%)$ & $18(42.85 \%)$ & $24(57.14 \%)$ & \multirow{7}{*}{$\begin{array}{c}95 \% \\
\text { (Illiterate) }\end{array}$} & \multirow[t]{7}{*}{1.000} \\
\hline $11-20$ & $54(15.78 \%)$ & $22(40.74 \%)$ & $32(59.25 \%)$ & & \\
\hline 21-30 & $67(19.59 \%)$ & $28(41.79 \%)$ & $39(58.20 \%)$ & & \\
\hline $31-40$ & $78(22.8 \%)$ & $33(42.30 \%)$ & $45(57.69 \%)$ & & \\
\hline 41-50 & $63(18.42 \%)$ & $27(42.85 \%)$ & $36(57.14 \%)$ & & \\
\hline$>50$ & $38(11.11 \%)$ & $16(42.10 \%)$ & $22(57.89 \%)$ & & \\
\hline Total & $342(5.45 \%)$ & $144(42.10 \%)$ & $198(57.89 \%)$ & & \\
\hline
\end{tabular}

In this study the highest infestation rate of scabies in Duhok province recorded in February with $15.10 \%$, and lowest infestation rate recorded in April with 9.8\%, and in Duhok refugees' camps the highest infestation percentage recorded in January (19.90\%) and lowest percentage in July $(6.70 \%)$ which are shown in figure No. (1).

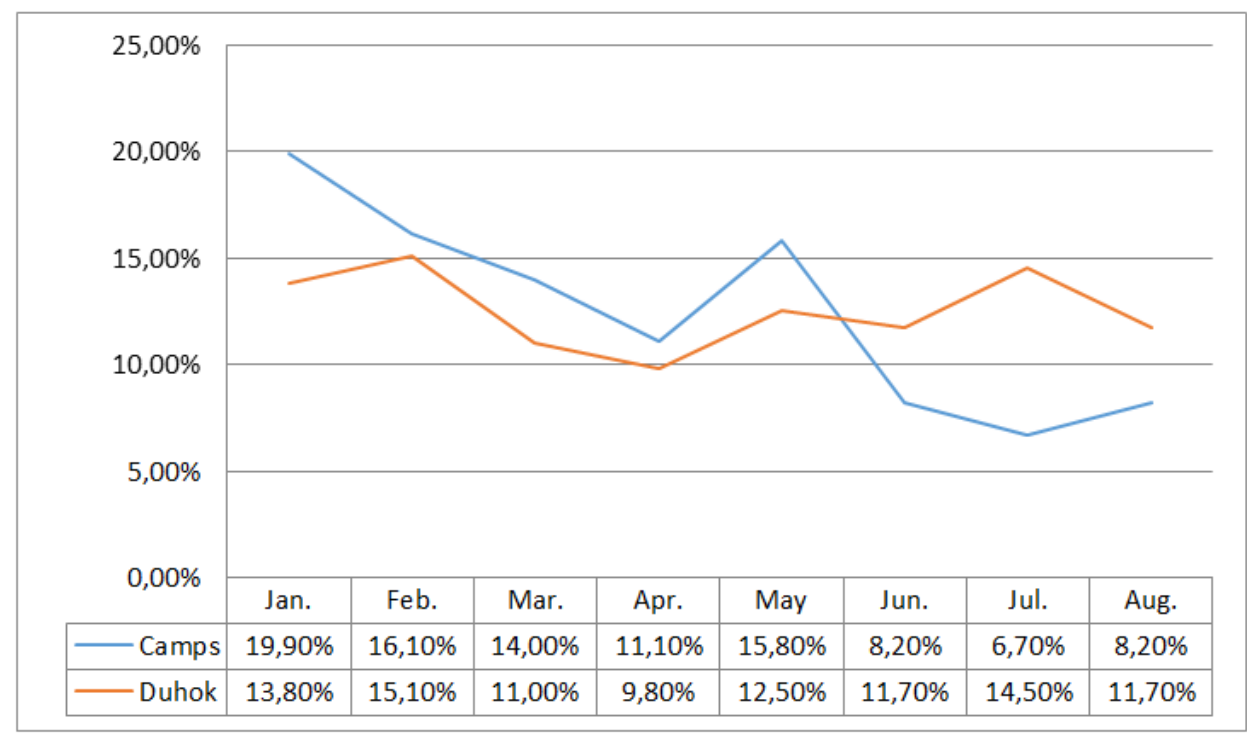

Figure (1): Monthly prevalence of Scabies in Duhok and refugee/IDP camps

According to education status of infested patients $85 \%$ of infested patients in Duhok province (Tab. No. 1), and $95 \%$ of infested patients in Duhok refugees' camps (Tab. No. 2), was recorded illiterate. The significant level of difference was determined in a P-value of less than 0.05 , in which there is no significant difference in records. 


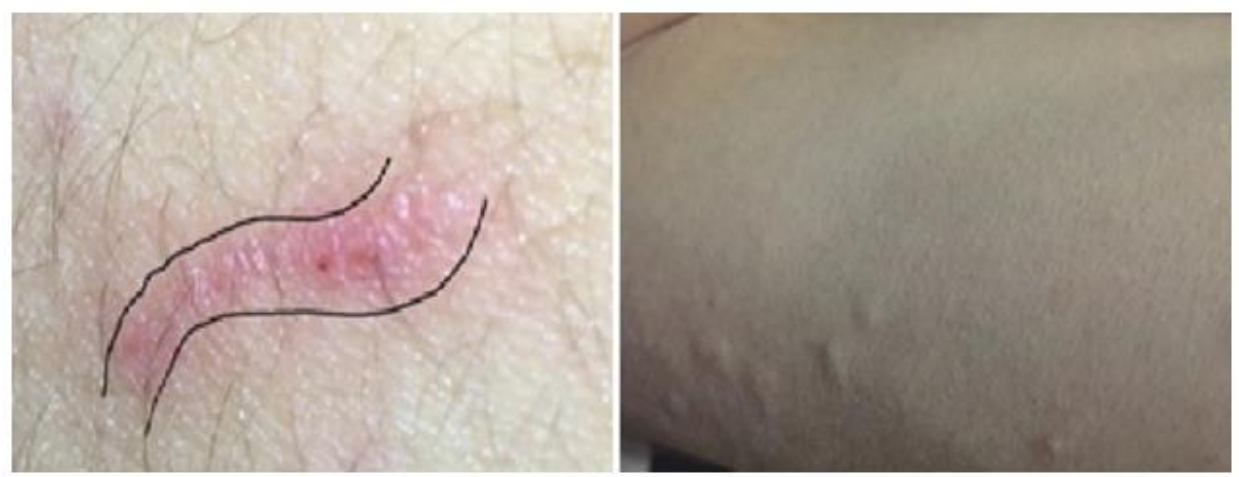

Figure (2): S-shaped burrow(lined) and skin rashes on the arm of a patient infested with scabies.

\section{Discussion}

Sarcoptes scabiei is one of the most important cutaneous ectoparasite in human which causes scabies. (Micali et al., 2016). In our region there are low investigations about prevalence study and risk factors of this ectoparasite. In current study $5.52 \%$ of infested individuals was recorded by this parasite in Duhok province, also $47.58 \%$ of infested patients in male and $52.41 \%$ of infestation are shown in female (Table No. 1), in Duhok refugees' camps (Table No. 2), the infested rate was recorded in 5.45\% with $42.10 \%$ in male and $57.89 \%$ in female. The infested percentage of Duhok province and Duhok refugees' camps are very close. Several factors such as poor housing, illiteracy, social relation and people behavior assist and facilitate the scabies transmission and the results of this study are in agreement with Mero and Hassan (2014), which they recorded, 5.56\% of infestation by scabies in their research. Results of this study is more similar with of findings of Daliri and Shafiei, (1994), which they reported $5.9 \%$ of scabies in their studies. Barwari, (2016), reported $4.5 \%$ of infestation by scabies in his study, which is lower than our records. Landwehr and his colleagues (1998) reported 4\% of scabies in Malawi and Cambodia in their research which is also lower than our findings. Odueko et al. (2001); Hegazy et al. (1999) reported that there is high difference of scabies infestation according to economical level of people. In current study the rates of scabies infestation in female are shown in higher than that of the male which is agree with Mero and Hassan (2014); Lassa et al. (2011); Ciftci et al. (2006); Golchai et al. (2003). On the other hand, there are other studies which their findings disagree with current study results. Barwari (2016) and Mason et al. (2016) were demonstrated higher percentage of infestation in male than in female which is disagree with our results. Females are more exposure to scabies infestation which may result from the work performance type, daily house activities, poor hygienic, socio-economic status and overcrowding (Olasode and Onayemi, 1998). Also according to age groups, in current study the highest rates of scabies infestation were obvious in age groups 31-40 years, the higher prevalence in this age group may be due to several factors such as: Overcrowding, working type and bad living conditions of patients which our results are in accordance with results of Jaberhashemi et al. (2018) and are not in accordance with Mero and Hassan (2014); AlShawa (2007); El- Okbi et al. (1993). However, several researches reported regardless of scabies infestation with sex and age (Arlian et al., 1988). Which are shown in Figure No. 1, the monthly prevalence of scabies in Duhok province and Duhok refugees' camps are recorded in high percentages in January and February and low percentages in April and July, which agree with Liu et al. (2016) and Ahmed and Aftabuddin, (1977). The ideal figure should show decreasing incidence of scabies with increasing temperature as from left to right, but here because of the different temperature, humidity rates among places belonging to Duhok province (Bardarash, Zakho, Semel, Duhok) the figure shows rise in the scabies incidence in middle of the figure. Also many studies indicate that there is inverse relation between temperature and scabies disease, which in high temperature decrease the activity of this parasite and in low temperature this parasite has more activity with high rate of fertility, (Estes SA\&Estes J, 1993; Arlian et al., 1984). According to education status (Table No. 1 and 2), the high percentage of infestation is among illiterates patients in both Duhok province and Duhok refugees' camps which is agree with Mero and Hassan (2014), and our study results are accordance with Ciftci et al. (2006), which reported low education level is related with high infestation rate. In this study, it was 27 | $P$ a g e www.iiste.org 
shown that there is wide distribution of scabies in some areas, and outbreaks possibility is high, therefore scabies treatment is very important.

\section{Conclusion}

The high incidence of scabies infestation occurs in Duhok province and Duhok refugees' camps can be as a result of some special factors such as poor personal hygiene, seasonal weather changes, also there is more exposure of females and patients with age group of (31-40) to scabies infestation, scabies is more prevalent in winter.

\section{Recommendations}

The important points of recommendation are using control and preventive measures by particular and proper health programs, as follow:

1. Personal education and good individual hygiene is very important to control this disease.

2. In overcrowded families all members of the affected family should be treated and any others who have had recent, prolonged contact with the infested individual.

3. Bedding, clothing and towels used during the previous three days should be washed in a hot water and dried in a hot dryer.

4. Care should be taken to coat the entire skin surface (from neck and down in adults) with medication especially webs of fingers and toes, not just symptomatic areas,

5. On the other hand, early diagnosis and treatment of infested person are the major steps of scabies prevention.

\section{Acknowledgements}

We would like to thank all health centers staff in Duhok, Zakho, Semel, Bardarash and directorates of refugees' camps and Dr. Aziz H. Kret /Health Facility Supervisor (Chameshko camp). Dr. Saidow A. Haidar /field Assistant in Darkar camp PHCC, Dr. Hazim H. Khalaf /Bersive 2 PHCC Manager, Mr. Mahmoud M. Khalaf/Director of the Bersif Camp 1 Health Center.

\section{References}

Al-Shawa, R.M. (2007). The epidemiology of Scabies in Gaza Governorates. Journal of Al- Azhar University-Gaza Natural Sciences 9:13-20.

Ahmed, S., Aftabuddin, A.K. (1977). Common skin diseases analysis of 7636 cases. Bangladesh Medical Research Council Bulletin 3(1), 41-45.

Arlian, L.G., Ahmed, M., Vyszenski-Moher, D. L. (1988). Effects of S. scabiei var. canis (Acari: Sarcoptidae) on blood indexes of parasitized rabbits. J Med Entom;25 (5): 360-9.

Arlian, L.G., Runyan, R.A., Achar, S., Estes, S.A. (1984). Survival and infestivity of Sarcoptes scabiei var. canis and var. hominis. Journal of the American Academy of Dermatology 11(2), 210-215.

Barwari, W. (2016). Prevalence of scabies among refugees in camps of Duhok province, Kurdistan region, Iraq. Duhok Medical Journal Volume 10, Issue 2.

Chosidow, O., (2006). Scabies. N Engl J Med. 354(16): 1718-1727.

Ciftci, I.H., Karaca, S. and Dogru, O. (2006). Prevalence of pediculosis and scabies in preschool nursery children of Afyon, Turkey Korean. J. Parasitol., 44:95-8.

Daliri, S., Shafiei, A. (1994). Scabies and impetigo in primary school students in Anzali port World Health. J.; 8: 57-9.

Elder, B.L., Arlian, L.G. and Morgan, M.S. (2006). Sarcoptes scabiei (Acari: Sarcoptidae) mite extract modulates expression of cytokines and adhesion molecules by human dermal microvascular endothelial cells. J Med Entomol 43(5): 910-5.

28| P a g e

www.iiste.org 
El-Okbi, L.M., Sarwat, M.A., El Sayed, M.H. and El Deeb, H.K. (1993). An epidemiological studies on human scabies in Cairo. J. Egypt Soc. Parasitol 23:795-808.

Engelman, D., Kiang, K. and Chosidow, O. (2013). Toward the Global Control of Human Scabies: Introducing the International Alliance for the Control of Scabies. PLoS Negl Trop Dis. 7(8): 2167-2169.

Estes, S.A. and Estes, J. (1993). Therapy of scabies: nursing homes, hospitals, and the homeless Seminars in Dermatology. 12(1), 26-33.

Golchai, J., Zargari, O., Gholipour, M. and Karbasi, M. (2003). The prevalence of Scabies in the students of primary schools in Somea-Sara in 2000-01: An observational cross-sectional study Iranian. J. Derma.,32-29.

Hay, R.J., Steer, A.C. and Engelman, D. (2012). Scabies in the developing world-its prevalence, complications, and management. Clin Microbiol Infect.; 18(4): 313-323.

Hegazy, A. Darwish, N.M., Abdel-Hamid, I.A. and Hammad, S.M. (1999). Epidemiology and control of scabies in an Egyptian village. Int J Dermatol.; 38(4): 291-5.

Hengge, U.R., Currie, B.J. and Jäger, G. (2006). Scabies: a ubiquitous neglected skin disease. Lancet Infect Dis.; 6(12): 769-779.

Jaberhashemi, S.A., Khosravani, M., Rafatpanah, A. and Nodez, S.M. (2018). The characteristics of scabies in human community in Bashagard district, Iran. Journal of Entomology and Zoology Studies JEZS; 6(2): 2859-2862.

Jarmuda, S., O'Reilly, N., Zaba, R., Jakubowicz, O., Szkaradkiewicz, A. and Kavanagh, K. (2012). Potential role of Demodex mites and bacteria in the induction of rosacea. J Med Microbiol.; 61(Pt 11): 1504-10.

Landwehr, D., Keita, S.M., Ponnighaus, J.M. and Tounkara, C. (1998). Epidemiologic aspects of scabies in Mali, Malawi, and Cambodia. Int J. Dermatol.; 37(8): 588-90.

Lassa, S., Campbell, M.J. and Bennett, C.E. (2011). Epidemiology of scabies prevalence in the U.K. general practice records. Br. J. Dermatol., 164:1329-34.

Liu, J.M. and Wang, H.W. (2016). The effects of climate factors on scabies. A 14-year populationbased study in Taiwan. Chang F-W, Liu Y-P, Chiu F-H, Lin Y-C, Cheng K-C \& Hsu R-J: Parasite, 23, 54.

Mason, D.S., Marks, M., Sokana, O., Solomon, A.W., Mabey, D.C., Romani, L., Kaldor, J., Steer, A.C. and Engelman, D. (2016). The prevalence of scabies and impetigo in the Solomon Islands: a population-based survey. PLoS Negl. Trop. Dis., 10(6): e0004803.

Mero, W.M.S. and Hassan, H.K. (2014). Incidence of human scabies in duhok province, Kurdistan Region/ Iraq. Journal of University of Zakho, Vol. 2(A), No.2, Pp 285-292.

Micali, G., Lacarrubba, F., Verzì, A.E., Chosidow, O. and Schwartz, R.A. (2016). Scabies: Advances in Noninvasive Diagnosis. PLoS Negl. Trop. Dis., 10(6): e0004691.

Mounsey, K.E., McCarthy, J.S. and Walton, S.F. (2013). Scratching the itch: new tools to advance understanding of scabies.Trends Parasitol.; 29(1): 35-42.

Odueko, O.M., Onayemi, O. and Oyedeji, G.A. (2001). A prevalence survey of skin diseases in Nigerian children. Niger J Med.; 10(2): 64-7.

29 | P a g e

www.iiste.org 
Olasode ,O.A. and Onayemi, O. (1998). Scabies: revisit in a depressed economy. Cent Afr J Med.; 44(1): 18-21.

Otero, L., Varela, J.A. and Espinosa, E. (2004). Sarcoptes scabiei in a sexually transmitted infections unit: a 15-year study. Sex Transm Dis. 31(12): 761-764.

Thomas, J., Peterson, G.M. and Walton, S.F. (2015). Scabies: an ancient global disease with a need for new therapies. BMC Infect Dis.; 15(250): 1-6.

Walton, S.F. and Currie, B.J. (2007). Problems in Diagnosing Scabies, a Global Disease in Human and Animal Populations. Clin Microbiol Rev.; 20(2): 268-279.

Walton, S.F. (2010). The immunology of susceptibility and resistance to scabies. Parasite Immunol; 32(8): 532-540. 